\title{
Further studies of the dynamics of nitrogen metabolism in sheep
}

\author{
By J. V. NOLAN, B. W. NORTON* AND R. A. LENG \\ Department of Biochemistry and Nutrition, Faculty of Rural Science, \\ The University of New England, Armidale, New South Wales 235r, Australia
}

$$
\text { (Received 10 Fune 1975-Accepted 21 Ÿuly 1975) }
$$

I. A study of ammonia and urea metabolism in sheep was made using isotope dilution techniques with $\left({ }^{15} \mathrm{NH}_{4}\right)_{2} \mathrm{SO}_{4},\left[{ }^{15} \mathrm{~N}\right]$ urea and $\left[{ }^{14} \mathrm{C}\right]$ urea in order to determine quantitatively the movements of urea- $\mathrm{N}$ and $\mathrm{NH}_{3}-\mathrm{N}$ throughout the body of normal, feeding sheep.

2. Single injections of ${ }^{15} \mathrm{~N}$-labelled compounds were made into the rumen fluid $\mathrm{NH}_{3}$, caecal fluid $\mathrm{NH}_{3}$ and the blood urea pools, in order to estimate the rates of flux through, and the transfer of $\mathrm{N}$ between, these and other nitrogenous pools in the body. ${ }^{51} \mathrm{Cr}$ EDTA was injected into the rumen and caecum with $\left({ }^{15} \mathrm{NH}_{4}\right)_{2} \mathrm{SO}_{4}$ to allow estimation of fluid volumes and to provide an indication of mixing, and of times of transit of isotopes between different sampling sites in the digestive tract.

3. The sheep ate approximately $22 \mathrm{~g}$ lucerne chaff/h and the mean dietary $\mathrm{N}$ intake was $16 \cdot 3 \mathrm{~g} / \mathrm{d}$.

4. The rate of flux of $\mathrm{NH}_{3}$ through the rumen $\mathrm{NH}_{3}$ pool was ${ }^{\circ} \cdot 0 \mathrm{~g} / \mathrm{d}$ (i.e. $90 \%$ of the dietary $\mathrm{N}$ ingested; however, this amount also included $\mathrm{N}$ from plasma urea $(\mathrm{I} \cdot \mathrm{I} g / \mathrm{d})$ and other endogenous sources including $\mathrm{NH}_{3}$ derived from caecal $\mathrm{NH}_{3}(0.4 \mathrm{~g} / \mathrm{d})$.

5. Only $40 \%$ of the $\mathrm{N}$ in isolated rumen bacteria was derived from $\mathrm{NH}_{3}$, indicating that a considerable proportion of their $\mathrm{N}$ requirements were obtained from compounds other than $\mathrm{NH}_{3}$ (e.g. peptides and amino acids).

6. There was evidence of recycling of $\mathrm{N}$ between nitrogenous pools in the rumen, probably through rumen $\mathrm{NH}_{3} \rightarrow$ microbial $\mathrm{N} \rightarrow \mathrm{NH}_{3}$.

7. It was estimated that $5.3 \mathrm{~g}$ blood urea-N/d entered the digestive tract: $20 \%$ of this urea was degraded in the rumen, $25 \%$ in the caecum and the remainder was apparently degraded elsewhere; there was evidence of urea degradation in the large intestine posterior to the caecum and it is suggested that urea degradation and absorption of the resultant $\mathrm{NH}_{\mathrm{a}}$ may occur in the ileum.

8. Of the $4.8 \mathrm{~g} \mathrm{~N} / \mathrm{d}$ entering the caecal $\mathrm{NH}_{3}$ pool, $4.2 \mathrm{~g} \mathrm{~N} / \mathrm{d}$ left and did not return and the difference $(0.6 \mathrm{~g} \mathrm{~N} / \mathrm{d})$ was recycled, possibly through caecal $\mathrm{NH}_{3} \rightarrow$ microbial $\mathrm{N} \rightarrow \mathrm{NH}_{3}$.

9. A large proportion of the $\mathrm{NH}_{3}$ entering the caecal $\mathrm{NH}_{3}$ pool $(70 \%$ or $3.2 \mathrm{~g} \mathrm{~N} / \mathrm{d})$ was apparently derived from degradation of nitrogenous products, other than urea, including rumen microbial $\mathrm{N}(\mathrm{r} \cdot \mathrm{\circ} \mathrm{g} / \mathrm{d})$ passing undigested from the small intestine.

Io. Less than half the $\mathrm{NH}_{3}-\mathrm{N}$ of caecal origin entering the rumen passed through the blood urea pool; the remainder was apparently transported as other nitrogenous compounds in the blood or body fluids.

II. The results of the three experiments were combined in a general three-pool, opencompartment model which formally recognizes an unlimited number of other unspecified, interconnected pools together comprising the whole-animal system. Rates of flux through, and transfer of $\mathrm{N}$ between these and other nitrogenous pools in the body were calculated by solving this model and the information derived has been applied to whole-animal models with a view to subsequently using these models in computer simulation studies.

Hydrolysis of endogenous urea to carbon dioxide and ammonia occurs in the digestive tract of all animals and appears to depend on urease $(E C 3.5 \cdot 1 \cdot 5)$ of bacterial origin (see e.g. Levenson, Crowley, Horowitz \& Malm, I959). In the

* Present address : Department of Agriculture, University of Queensland, St Lucia, Queensland 4067, Australia. 
ruminant $\mathrm{NH}_{3}$ is available for microbial cell growth and microbial protein synthesized from recycled urea-nitrogen provides the animal with an additional source of available protein.

In most studies of $\mathrm{NH}_{3}$ and urea metabolism in ruminants, certain aspects of $\mathrm{N}$ metabolism (e.g. transfer of urea from the blood to the rumen) have been studied in isolation rather than as part of a comprehensive study of $\mathrm{N}$ metabolism in the intact, feeding animal. Such comprehensive studies are necessary if $\mathrm{N}$ metabolism in the normal, feeding animal is to be more fully understood. Recently, a whole-animal model incorporating values for $\mathrm{N}$ transfer by pathways that appear to be biologically important was developed from results of isotope dilution studies with ${ }^{14} \mathrm{C}$ - and ${ }^{15} \mathrm{~N}$-labelled compounds, for sheep given lucerne chaff (Nolan \& Leng, 1972). This model indicated that transfer of urea from the blood to the rumen was quantitatively less important as a mechanism for providing $\mathrm{N}$ in the rumen than had been previously suggested, and the results seemed to indicate that there was an important site of endogenous urea degradation in the lower digestive tract.

These earlier studies (Nolan \& Leng, 1972) have now been extended to include direct measurement of the exchanges of $\mathrm{N}$ between pools in the blood, caecum and rectum as well as the rumen.

To obtain quantitative estimates of these exchanges of $\mathrm{N}$ in the body, three experiments were done using three different sheep given the same diet. Each experiment produced considerable information for one animal, but the maximum amount of information was obtained when the three experiments were interpreted as a single study representative of the normal, feeding animal.

\section{MATERIALS AND METHODS}

Experimental animals

Three Merino ewes ( $L, J$ and S; aged 2-3 years) were each fitted with a rumen cannula and also a cannula inserted into the pole of the caecum, $30 \mathrm{~mm}$ from the blind end. The animals were housed singly in pens and given $800 \mathrm{~g}$ chaffed lucerne hay ( $187 \mathrm{~g}$ crude protein $(\mathrm{N} \times 6 \cdot 25) / \mathrm{kg}) / \mathrm{d}$ for several months before the isotope studies were begun. At least 2 weeks before each experiment, the ewes were placed in metabolism cages in a room that was continuously illuminated. For I week before administration of isotopes, the ewes were given their daily ration in $33 \mathrm{~g}$ portions each hour. The actual mean intakes of dry matter (DM) are given in Table I (i.e. about $70 \%$ of that offered was eaten).

\section{Experimental procedure}

Catheters were inserted into both jugular veins of an animal $12 \mathrm{~h}$ before each experiment, one to administer the isotopes and the other to sample blood.

In the first experiment with sheep $\mathrm{L}$, a single injection of $\left({ }^{15} \mathrm{NH}_{4}\right)_{2} \mathrm{SO}_{4}(226 \mathrm{mg}$, 96 atoms/roo atoms ${ }^{15} \mathrm{~N}$ ) and ${ }^{51} \mathrm{Cr}$ EDTA (100 $\mu \mathrm{Ci}$ ) both dissolved in $100 \mathrm{ml}$ water was made into the ventral sac of the rumen. The solution was administered through a funnel connected to a plastic tube that was directed into various parts of the reticulo- 
rumen to disperse the isotopes throughout the contents. After I min, $\left[{ }^{14} \mathrm{C}\right]$ urea ( $5 \circ \mathrm{mg} ; 5 \circ \mu \mathrm{Ci}$ ) in $10 \mathrm{ml}$ isotonic saline was injected intravenously.

In the second experiment a single intravenous injection of $10 \mathrm{ml}$ of a mixture of $\left[{ }^{15} \mathrm{~N}\right]$ urea (100 mg, 96 atoms/100 atoms ${ }^{15} \mathrm{~N}$ ) and $\left[{ }^{14} \mathrm{C}\right]$ urea $(50 \mathrm{mg} ; 50 \mu \mathrm{Ci}$ ) was given to sheep J.

In the third experiment $\left({ }^{15} \mathrm{NH}_{4}\right)_{2} \mathrm{SO}_{4}\left(226 \mathrm{mg}, 96\right.$ atoms/100 atoms $\left.{ }^{15} \mathrm{~N}\right)$ and ${ }^{51} \mathrm{Cr}$ EDTA (100 $\mu \mathrm{Ci}$ ) dissolved in $50 \mathrm{ml}$ water was injected into the caecum of sheep $\mathrm{S}$ through a water-tight seal in the plug of the caecal cannula. A single injection of $\left[{ }^{14} \mathrm{C}\right]$ urea $(50 \mathrm{mg} ; 50 \mu \mathrm{Ci})$ in isotonic saline was given intravenously at about the same time.

Samples of rumen fluid, caecal digesta, faecal pellets and blood were taken before (to give the pre-injection levels of isotope in each type of sample) and at frequent intervals during the $3 \mathrm{~d}$ after the injection of isotopic tracers.

For $3 \mathrm{~d}$ before and $4 \mathrm{~d}$ after the beginning of each experiment, daily collections of urine and faeces were made. These were mixed and subsampled daily and a composite sample of each was subsequently analysed.

\section{Sampling}

Rumen fluid, faeces and blood samples were taken and processed as described previously (Nolan \& Leng, 1972).

Caecal digesta were obtained by scooping material (using a small plastic spoon) through the caecal cannula into a weighed plastic tube containing $5 \mathrm{ml} \mathrm{o.} 5 \mathrm{M}-\mathrm{H}_{2} \mathrm{SO}_{4}$. Faecal samples were put into similarly prepared plastic tubes. The contents of these tubes were then homogenized and a small portion was taken for DM determination. The remaining contents were centrifuged at $19000 \mathrm{~g}$ for $20 \mathrm{~min}$. The supernatant solution was retained and kept at $-20^{\circ}$ and subsequently $\mathrm{NH}_{3}$ was isolated from it. The solid material was resuspended and then washed three times with isotonic saline containing a detergent, as described previously for isolation of rumen bacteria (see Nolan \& Leng, 1972). Since no clear separation of bacteria was obtained by centrifugation, the washed particulate materials are hereafter referred to as 'caecal debris' or 'faecal debris'.

The blood plasma was stored at $-20^{\circ}$. Urine was collected by suction from a rubber collector held around the vagina by contact adhesive according to the method of Raabe (1968). This method allows urine to be collected quantitatively as it is voided, thereby preventing faecal contamination. A bulked sample of urine made up of daily subsamples was stored at $-20^{\circ}$.

\section{Laboratory procedures}

All nitrogenous samples were processed to transfer their $\mathrm{N}$ to $\left(\mathrm{NH}_{4}\right)_{2} \mathrm{SO}_{4}$ as required for ${ }^{15} \mathrm{~N}$ analysis in a mass spectrometer (see Nolan \& Leng, 1972). The specific radioactivity of urea-C in plasma samples was estimated as described by Nolan \& Leng (1970) and the specific radioactivity of ${ }^{51} \mathrm{Cr}$ EDTA in rumen and caecal supernatant solutions was determined using a gamma spectrometer (Packard Instrument Co., Illinois, USA). The concentration of urea in urine was determined 
using an AutoAnalyzer (Technicon Instruments Corporation, Tarry Town, New York, USA) using the diacetyl monoxime method of Marsh, Fingerhut \& Kirsch (1957). The $\mathrm{N}$ content of the food, faeces and urine was determined as described by Clare \& Stevenson (1964).

\section{Mathematical procedures}

Analysis of ${ }^{14} \mathrm{C}$ and ${ }^{15} \mathrm{~N}$ tracer experiments. The equations for the lines which were fitted to the specific radioactivities or enrichment values in samples taken from various pools after isotope injection were of the general form:

$$
\begin{aligned}
S R_{t} & =\sum_{i=1}^{n} \mathrm{~A}_{i} e^{-m_{i} \mathrm{t}}, \\
E_{t} & =\sum_{i=1}^{n} \mathrm{~A}_{i} e^{-m_{i} \mathrm{t}},
\end{aligned}
$$

where $t$ is time (min), $S R_{t}$ is specific radioactivity ( $\mu \mathrm{Ci} / \mathrm{g}$ ) of plasma urea at time $t$, $E_{t}$ is enrichment of $\mathrm{N}$ in a nitrogenous fraction (atoms/100 atoms excess) at time $t$, A is zero-time intercept of each exponential component ( $\mu \mathrm{Ci} / g$ urea or atoms/10o atoms excess), $m$ is rate-constant of each component $(/ \mathrm{min}), n$ is number of exponential components, $i$ is exponential component number.

Equations for the lines describing the changes with time of specific radioactivity of $\mathrm{C}$ or enrichment of $\mathrm{N}$ in compounds in primary pools (i.e. pools into which isotopes were injected) were estimated with the aid of a computer programme. Some secondary pools (i.e. build-up and decay curves) could not be fitted by available multiexponential curve-fitting techniques which assume a model in which all pools interact simultaneously, since the results indicated that this assumption was not compatible with the experimental results. For example, following intraruminal ${ }^{15} \mathrm{NH}_{4}{ }^{+}$injection, ${ }^{15} \mathrm{~N}$ may arrive in the pools of $\mathrm{N}$ in the hind gut quite rapidly by way of the blood and more slowly by passage along the digestive tract, and thus some secondary curves in the hind gut showed complex forms. In instances where complex curves appeared feasible on biological grounds, these were fitted to the results by eye and the areas under these curves were obtained by planimetery (see Nolan \& Leng, 1974). The area (X) under fitted multi-exponential curves was estimated by integrating the previous equations (above), from zero-time to infinity, which gives:

$$
\mathrm{X}=\sum_{i=1}^{n} \frac{\mathrm{A}_{i}}{m_{i}}
$$

Calculations of pool size, total flux rate, irreversible loss rate and recycling rate with respect to the pool into which an isotope was injected were calculated, from the equations to the curves, by standard procedures (see White, Steel, Leng \& Luick, 1969).

The proportion $(Q)$ of the $\mathrm{N}$ in any secondary pool $(S)$ derived from a primary pool $(P)$ was given by:

$$
Q=\frac{\text { area under the enrichment curve for pool } S}{\text { area under the enrichment curve for pool } P} \text {. }
$$


Table I. Live weight, intake and faecal excretion $(\mathrm{g} / \mathrm{d})$ of dry matter (DM) and nitrogen, and urinary $N$ excretion $(\mathrm{g} / d)$ for sheep eating chaffed lucerne hay

(Measurements were made during $7 \mathrm{~d}$ digestibility trials so that the $\mathrm{ist}$ day of the digestibility trial coincided with the day of injections of tracers in each of the three experiments*)

\begin{tabular}{|c|c|c|c|c|c|c|c|c|}
\hline \multirow[b]{2}{*}{ Sheep } & \multirow{2}{*}{$\begin{array}{c}\text { Expt } \\
\text { no. }\end{array}$} & \multirow{2}{*}{$\begin{array}{l}\text { Live wt } \\
\text { (kg) }\end{array}$} & \multicolumn{2}{|c|}{ Intake } & \multicolumn{2}{|c|}{ Faecal excretion } & \multicolumn{2}{|c|}{ Urinary excretion } \\
\hline & & & DM & $N$ & $\mathrm{DM}$ & $\vec{N}$ & Total N & Urea-N \\
\hline $\mathrm{L}$ & I & $3^{I}$ & 459 & 13.7 & r49 & $4 \cdot I$ & $12 \cdot 0$ & 9.5 \\
\hline $\mathbf{J}$ & 2 & 35 & $5^{2} 3$ & I5.6 & 193 & $5 \cdot 9$ & 13.2 & 10.5 \\
\hline $\mathrm{S}$ & 3 & $3^{x}$ & 588 & $19 \cdot 6$ & 228 & $6 \cdot 5$ & 10.2 & 8.0 \\
\hline Mean & & 32 & 523 & $16 \cdot 3$ & 190 & $5 \cdot 5$ & II $\cdot 8$ & $9 \cdot 3$ \\
\hline SE & & $x \cdot 3$ & 37 & $x \cdot 7$ & 8 & 0.7 & 0.9 & 0.7 \\
\hline
\end{tabular}

Table 2. Concentrations of ammonia (mg nitrogen/l) in rumen, caecal and faecal fuids, and concentrations of urea (mg N/l) in plasma of sheep during the $3 d$ periods of the isotope dilution experiments

(Values in parentheses are coefficients of variation)

\begin{tabular}{|c|c|c|c|c|c|c|}
\hline \multirow[b]{2}{*}{ Sheep } & \multirow{2}{*}{$\begin{array}{l}\text { Expt } \\
\text { no. }\end{array}$} & \multirow[b]{2}{*}{ Tracer injection* } & \multicolumn{3}{|c|}{$\mathrm{NH}_{3}$ concentration } & \multirow{2}{*}{$\begin{array}{c}\text { Plasma } \\
\text { urea } \\
\text { concentration }\end{array}$} \\
\hline & & & Rumen fluid & Caecal fluid & Faecal fluid & \\
\hline L & $\mathbf{I}$ & $\begin{array}{c}\text { Intraruminal } \\
\left({ }^{15} \mathrm{NH}_{4}\right)_{2} \mathrm{SO}_{4}\end{array}$ & $279(37)$ & $47 \times(37)$ & $547(42)$ & $183(5)$ \\
\hline $\mathrm{J}$ & 2 & $\begin{array}{l}\text { Intravenous } \\
{\left[{ }^{15} \mathrm{~N}\right] \text { urea }}\end{array}$ & $238(28)$ & $266(62)$ & $653(59)$ & $154(7)$ \\
\hline $\mathbf{S}$ & 3 & Intracaecal & III (24) & $291(50)$ & $\operatorname{II}_{5}\left(3^{8}\right)$ & $207(3)$ \\
\hline $\begin{array}{l}\text { Mean } \\
\text { SE }\end{array}$ & & & $\begin{array}{r}209 \\
5 x\end{array}$ & $\begin{array}{l}343 \\
\text { I } 12\end{array}$ & $\begin{array}{l}438 \\
165\end{array}$ & $\begin{array}{r}181 \\
15\end{array}$ \\
\hline
\end{tabular}

* For experimental details, see pp. 128-9.

The rates of flow of $\mathrm{N}(\mathrm{g} / \mathrm{d})$ associated with rumen fluid $\mathrm{NH}_{3}$, plasma urea and caecal $\mathrm{NH}_{3}$ pools were obtained by solving a general, three-pool, open-compartment model using results of all three experiments (see Appendix).

Water kinetics in the rumen and caecum. The rates of movement of water through the rumen and caecum were calculated by methods which assumed that ${ }^{51} \mathrm{Cr}$ EDTA was not appreciably absorbed from the gut, that it moved with water in the digesta, and that first-order dilution processes were present (see Downes \& McDonald, I964).

\section{RESULTS}

Live weight, food intake, digestibility and $N$ retention

A summary of intake of DM and $\mathrm{N}$, faecal excretion of DM and $\mathrm{N}$, and urinary $\mathrm{N}$ excretion of the sheep is given in Table $\mathrm{I}$. 

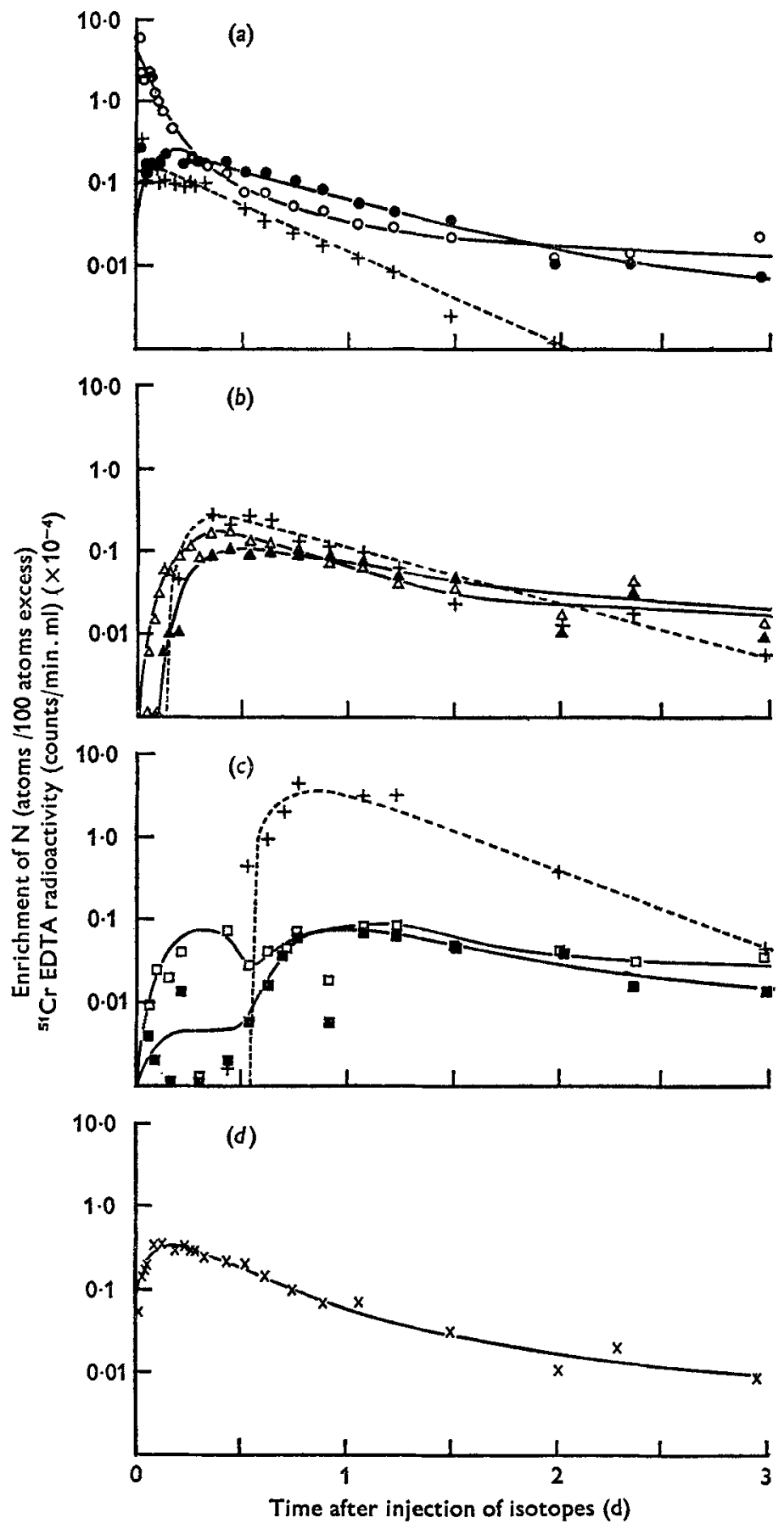

Fig. 1. Expt I. Injection of $\left({ }^{15} \mathrm{NH}_{4}\right)_{2} \mathrm{SO}_{4}$ and ${ }^{51} \mathrm{Cr}$ EDTA into the rumen. 'Enrichment-withtime' curves after a single injection of $\left({ }^{15} \mathrm{NH}_{4}\right)_{2} \mathrm{SO}_{4}$ into the rumen of sheep $\mathrm{L}$, for $(a)$ ammonia-nitrogen $(O)$ and bacterial $\mathrm{N}(\boldsymbol{O})$ in the rumen; $(b) \mathrm{NH}_{3}-\mathrm{N}(\triangle)$ and debris $\mathrm{N}(\Delta)$ in the caecum; $(c) \mathrm{NH}_{3}-\mathrm{N}(\square)$ and debris $\mathrm{N}(\boldsymbol{D})$ in the rectum; $(d)$ urea-N $(x)$ in the plasma. Injection of ${ }^{51} \mathrm{Cr}$ ED'TA was made simultaneously and its specific radioactivity with time after injection, in the water of the rumen, caecum and rectum is also given $(+)$. For experimental details, see pp. 128-9 and for explanation of 'debris', see p. 129. 
Table 3. Dynamic aspects of urea metabolism in the blood, and ammonia metabolism in the rumen and caecum of sheep during the $3 d$ periods of isotope dilution experiments

(Values across any line in the table refer only to the pool into which tracer was injected, and from which samples were taken)

\begin{tabular}{|c|c|c|c|c|c|c|c|}
\hline Sheep & $\begin{array}{c}\text { Expt } \\
\text { no. }\end{array}$ & $\begin{array}{l}\text { Tracer } \\
\text { injection* }\end{array}$ & Pool sampled & $\begin{array}{l}\text { Total flux } \\
\text { rate } \\
(\mathrm{g} \mathrm{N} / \mathrm{d})\end{array}$ & $\begin{array}{c}\text { Irreversible } \\
\text { loss rate } \\
(\mathrm{g} \mathrm{N} / \mathrm{d})\end{array}$ & $\begin{array}{c}\text { Recycling } \\
\text { rate } \\
(\mathrm{g} \mathrm{N} / \mathrm{d})\end{array}$ & $\begin{array}{l}\text { Size of } \\
\text { pool } \\
(\mathrm{g} \mathrm{N})\end{array}$ \\
\hline L & I & $\underset{\left({ }^{15} \mathrm{NH}_{4}\right)_{2} \mathrm{SO}_{4}}{\text { Intraruminal }}$ & Rumen $\mathrm{NH}_{3}-\mathrm{N}$ & $15 \cdot 0$ & $10 \cdot 7$ & 4.3 & $1 \cdot 46$ \\
\hline$J$ & 2 & $\begin{array}{l}\text { Intravenous } \\
{\left[{ }^{15} \mathrm{~N}\right] \text { urea }}\end{array}$ & Plasma urea-N & I $5 \cdot I$ & $13.5 t$ & $x \cdot 6$ & $3 \cdot 64$ \\
\hline $\mathbf{S}$ & 3 & $\begin{array}{l}\text { Intracaecal } \\
\left({ }^{15} \mathrm{NH}_{4}\right)_{2} \mathrm{SO}_{4}\end{array}$ & Caecal $\mathrm{NH}_{3}-\mathrm{N}$ & $4 \cdot 8$ & 4.2 & 0.6 & 0.14 \\
\hline $\mathbf{J}$ & 2 & $\begin{array}{l}\text { Intravenous } \\
{\left[{ }^{14} \mathrm{C}\right] \text { urea }}\end{array}$ & Plasma urea-C & I6.I & $15 \cdot 7 t$ & 0.4 & 3.50 \\
\hline
\end{tabular}

* For experimental details, see pp. 128-9.

$\dagger$ The rate of irreversible loss of urea- $N$ is a measure of the rate of urea synthesis from $N$ which has not already been recycled during the processes of urea degradation.

T The rate of irreversible loss of urea-C is a measure of total urea synthesis in the body.

\section{Concentrations of $\mathrm{NH}_{3}-\mathrm{N}$ and urea-N in sampled pools in sheep during a $3 d$ period after injection of isotopes}

The mean concentrations of $\mathrm{NH}_{3}-\mathrm{N}$ in rumen fluid, caecal fluid and faecal water, and urea- $\mathrm{N}$ in the plasma of sheep during the $3 \mathrm{~d}$ after injection of isotopes, are given in Table 2. Estimates of the variation in concentrations that occurred during these periods are also given.

\section{Expt $\mathrm{1}$. Single injection into the rumen of a solution containing $\left({ }^{15} \mathrm{NH}_{4}\right)_{2} \mathrm{SO}_{4}$}

The enrichment of $\mathrm{NH}_{3}-\mathrm{N}$ in the rumen fluid with time after a single, intraruminal injection of $\left({ }^{15} \mathrm{NH}_{4}\right)_{2} \mathrm{SO}_{4}$ into sheep $\mathrm{L}$ is given in Fig. $\mathrm{I} a$. The appearance of ${ }^{15} \mathrm{~N}$ in a number of secondary pools is shown in Fig. $1 a, b, c$ and $d$. The loss from the rumen of ${ }^{51} \mathrm{Cr}$ EDTA injected at the same time is also shown in Fig. $\mathrm{l} a$, and its appearance and change of concentration with time in some secondary pools in the digestive tract are given in Fig. $\mathrm{I} b, c$ and $d$. The results for ${ }^{51} \mathrm{Cr}$ EDTA indicated that the isotopes mixed rapidly throughout the rumen contents and that the rate of flow of water from the rumen was constant and obeyed first-order kinetics. The ${ }^{15} \mathrm{NH}_{3}$ 'enrichment-with-time' curve was well described by an equation which had three exponential components. Total flux rate, irreversible loss rate and recycling rate of $\mathrm{NH}_{3}$ with respect to the rumen $\mathrm{NH}_{3}$ pool were calculated from this equation (see Table 3, sheep L).

The volume of distribution of ${ }^{51} \mathrm{Cr}$ EDTA, and the rate of flow of water to the lower digestive tract are given in Table 4. The estimates of volume of distribution of ${ }^{51} \mathrm{Cr}$ EDTA (i.e. ${ }^{51} \mathrm{Cr}$ EDTA space or water space) and the water flow rate were used together with the mean rumen fluid $\mathrm{NH}_{3}$ concentration to give an alternative estimate of the size of the rumen fluid $\mathrm{NH}_{3}$ pool and of flow of $\mathrm{NH}_{3}-\mathrm{N}$ to the lower gut (Table 4). 
Table 4. Estimates of rumen and caecal fuid volumes and outflow rates for sheep obtained by analysing ${ }^{51} \mathrm{Cr}$ EDTA dilution results, and calculations of ammonia pool sizes and $\mathrm{NH}_{3}$ outflow rates made using measured $\mathrm{NH}_{3}$ concentrations (from Table 2) for these organs

\begin{tabular}{|c|c|c|c|c|c|c|c|}
\hline Sheep & $\begin{array}{l}\text { Expt } \\
\text { no. }\end{array}$ & $\begin{array}{l}\text { Tracer } \\
\text { injection* }\end{array}$ & $\begin{array}{c}\text { Pool } \\
\text { sampled }\end{array}$ & $\begin{array}{l}\text { Water } \\
\text { volume } \\
\text { (1) }\end{array}$ & $\begin{array}{l}\text { Water } \\
\text { outflow } \\
(1 / d)\end{array}$ & $\begin{array}{c}\mathrm{NH}_{3} \\
\text { outflow } \\
\text { in water } \\
\text { (g nitrogen } / \mathrm{d})\end{array}$ & $\begin{array}{c}\mathrm{NH}_{3} \\
\text { pool size } \dagger \\
\text { in water } \\
(\mathrm{g} \mathrm{N})\end{array}$ \\
\hline L & I & $\begin{array}{c}\text { Intraruminal } \\
{ }^{51} \mathrm{Cr} \text { EDT }\end{array}$ & Rumen water & $4 \cdot 42$ & 10.2 & $2 \cdot 85$ & $1 \cdot 24$ \\
\hline$S$ & 3 & $\begin{array}{l}\text { Intracaecal } \\
{ }^{51} \mathrm{Cr} \text { EDTA }\end{array}$ & Caecal water & 0.38 & 2.91 & 0.85 & O.II \\
\hline
\end{tabular}

* For experimental details, see pp. I28-9.

$\dagger$ Calculated as the product of ${ }^{51} \mathrm{Cr}$ EDTA space (l) and measured mean $\mathrm{NH}_{3}$ concentrations in rumen or caecal fluid $(\mathrm{g} N / \mathrm{l})$.

Table 5. Ratios of areas under the primary curves:areas under the secondary curves for 'enrichment-with-time' curves obtained from three isotope dilution experiments in which the primary pools were (I) rumen ammonia, (2) caecal $\mathrm{NH}_{3}$ and (3) blood urea; the primary and secondary curves under consideration are given in Figs. 1,2 and 3 respectively

(Each value within the table represents the percentage area under a secondary curve relative to the area under its primary curve taken as $100 \%$; it is thus an estimate of the proportion of the nitrogen atoms in the secondary pool derived from those in the primary pool)

\begin{tabular}{|c|c|c|c|}
\hline \multirow[b]{2}{*}{ Tracer injection } & \multicolumn{3}{|c|}{ Expt no. } \\
\hline & $\begin{array}{c}\text { I } \\
\text { Intraruminal } \\
\left({ }^{15} \mathrm{NH}_{4}\right)_{2} \mathrm{SO}_{4}\end{array}$ & $\begin{array}{c}3 \\
\text { Intracaecal } \\
\left({ }^{15} \mathrm{NH}_{4}\right)_{2} \mathrm{SO}_{4}\end{array}$ & $\begin{array}{c}2 \\
\text { Intravenous } \\
{\left[{ }^{15} \mathrm{~N}\right] \text { urea }}\end{array}$ \\
\hline Pool & & & \\
\hline Rumen $\mathrm{NH}_{3}-\mathrm{N}$ & 100 & 5 & I I \\
\hline Rumen bacterial $\mathbf{N}$ & 41 & - & 4 \\
\hline Caecal $\mathrm{NH}_{3}-\mathrm{N}$ & 39 & 100 & 32 \\
\hline Caecal debrist $\mathbf{N}$ & 35 & - & 4 \\
\hline Faecal $\mathrm{NH}_{3}-\mathrm{N}$ & 38 & 20 & 12 \\
\hline Faecal debrist $\mathbf{N}$ & 23 & 一 & 7 \\
\hline Plasma urea-N & 52 & I3 & 100 \\
\hline
\end{tabular}

The ratio, area under the curve for plasma $\left[{ }^{15} \mathrm{~N}\right]$ urea $v$. time: area under the curve for rumen ${ }^{15} \mathrm{NH}_{3} v$. time gave the proportion of the urea- $\mathrm{N}$ in plasma that was derived from rumen fluid $\mathrm{NH}_{3}$ (Table 5 , Expt $\mathrm{I}$ ).

The time between injection of ${ }^{51} \mathrm{Cr}$ EDTA into the rumen and appearance of radioactivity in caecal water (see Fig. $\mathrm{I} b$ ) gave an estimate of the time taken for water to move from the rumen through the digestive tract to the caecum; the time of first appearance was $377 \mathrm{~h}$ after the injection and the mean transit time, calculated as the time for appearance of $50 \%$ of the injected ${ }^{51} \mathrm{Cr}$ EDTA was $\mathrm{I} 8.3 \mathrm{~h}$ (Fig. I $b$ ). The latter value was assumed to indicate the mean time for passage for enriched nitrogenous fractions through the digestive tract from the rumen to the caecum. The curves 
describing appearance of ${ }^{15} \mathrm{~N}$ in caecal fluid $\mathrm{NH}_{3}$ and caecal debris reached maximum values at the same time as the maximum concentration of ${ }^{51} \mathrm{Cr}$ EDTA radioactivity in caecal water (Fig. $\mathrm{I} b$ ). The areas under the respective secondary curves for caecal fluid $\mathrm{NH}_{3}-\mathrm{N}$ and caecal debris $\mathrm{N}$ in relation to the area under the primary curve in rumen fluid $\mathrm{NH}_{3}-\mathrm{N}$ gave the proportions of $\mathrm{N}$ in caecal fluid $\mathrm{NH}_{3}$ and caecal debris arising from rumen $\mathrm{NH}_{3}$ (Table 5, Expt I).

The appearance of radioactivity from ${ }^{51} \mathrm{Cr}$ EDTA in the faecal water (Fig. $1 c$ ) was used as an indication of the expected time of first appearance in faeces of water from the rumen $(\mathrm{I} \cdot 3 \mathrm{~h})$ and of the mean transit time for passage of water from the rumen to the faeces through the digestive tract $(28 \cdot 0 \mathrm{~h})$. The appearance of ${ }^{15} \mathrm{~N}$ in faecal fluid $\mathrm{NH}_{3}$ and faecal debris preceded the arrival of water from the rumen, and the curves describing the changes in ${ }^{15} \mathrm{~N}$ content with time are apparently composed of at least two successive processes of build-up and decay (see Fig. Ic). The rate of synthesis of urea (irreversible loss rate) as estimated from intravenous injection of $\left[{ }^{14} \mathrm{C}\right]$ urea in this experiment was $15^{\cdot} \cdot \mathrm{g} \mathrm{N} / \mathrm{d}$.

\section{Expt 2. Single intravenous injection of a solution of $\left[{ }^{15} \mathrm{~N}\right]$ urea and $\left[{ }^{14} \mathrm{C}\right]$ urea}

The enrichment of plasma urea- $\mathrm{N}$ in the period following a single intravenous injection of $\left[{ }^{15} \mathrm{~N}\right]$ urea into sheep $\mathrm{J}$ is given in Fig. $2 a$. The experimental results were well described by a curve with three exponential components. The rate of decrease in specific radioactivity of urea-C in blood following the intravenous injection of $\left[{ }^{14} \mathrm{C}\right]$ urea was faster than that obtained simultaneously for enrichment in urea- $\mathrm{N}$ after injection of $\left[{ }^{15} \mathrm{~N}\right]$ urea. Simultaneous estimates of pool sizes, total flux rates, irreversible loss rates and recycling rates of urea- $\mathrm{C}$ and of urea- $\mathrm{N}$ are compared in Table 3 (sheep J).

The appearance curves for ${ }^{15} \mathrm{~N}$ in rumen fluid $\mathrm{NH}_{3}$ and rumen bacteria, and caecal fluid $\mathrm{NH}_{3}$ and caecal debris, and faecal fluid $\mathrm{NH}_{3}$ and faecal debris, fitted by eye, are given in Fig. $2 b, c$ and $d$. The curves describing the appearance of ${ }^{15} \mathrm{~N}$ in faecal water $\mathrm{NH}_{3}$ and faecal debris were apparently composed of at least two processes of build-up and decay (Fig. $2 d$ ). The ratios, area under each of these secondary curves: area under the primary curve describing the dilution of ${ }^{15} \mathrm{~N}$ in plasma urea, gave the proportions of each of the nitrogenous fractions arising from plasma urea (Table 5, Expt 2).

\section{Expt 3. Single injection of a solution containing $\left({ }^{15} \mathrm{NH}_{4}\right)_{2} \mathrm{SO}_{4}$ into the caecum}

The enrichment of $\mathrm{NH}_{3}$ in caecal fluid during the period after the injection of $\left({ }^{15} \mathrm{NH}_{4}\right)_{2} \mathrm{SO}_{4}$ solution into the caecum of sheep $\mathrm{S}$ is shown in Fig. $3 a$. The experimental results were well described by a curve with three exponential components, and the equation to the curve was used to calculate the pool size, the total flux rate, irreversible loss rate and recycling rate of $\mathrm{NH}_{3}-\mathrm{N}$ with respect to the caecal fluid $\mathrm{NH}_{3}-\mathrm{N}$ pool as described previously for measures of rumen fluid $\mathrm{NH}_{3}-\mathrm{N}$ metabolism (see Table 3, sheep S).

The decrease in radioactivity as ${ }^{51} \mathrm{Cr}$ EDTA in caecal fluid after simultaneous injection of ${ }^{51} \mathrm{Cr}$ EDTA and $\left({ }^{15} \mathrm{NH}_{4}\right)_{2} \mathrm{SO}_{4}$ (Fig. $3 a$ ) gave an indication of the mixing 

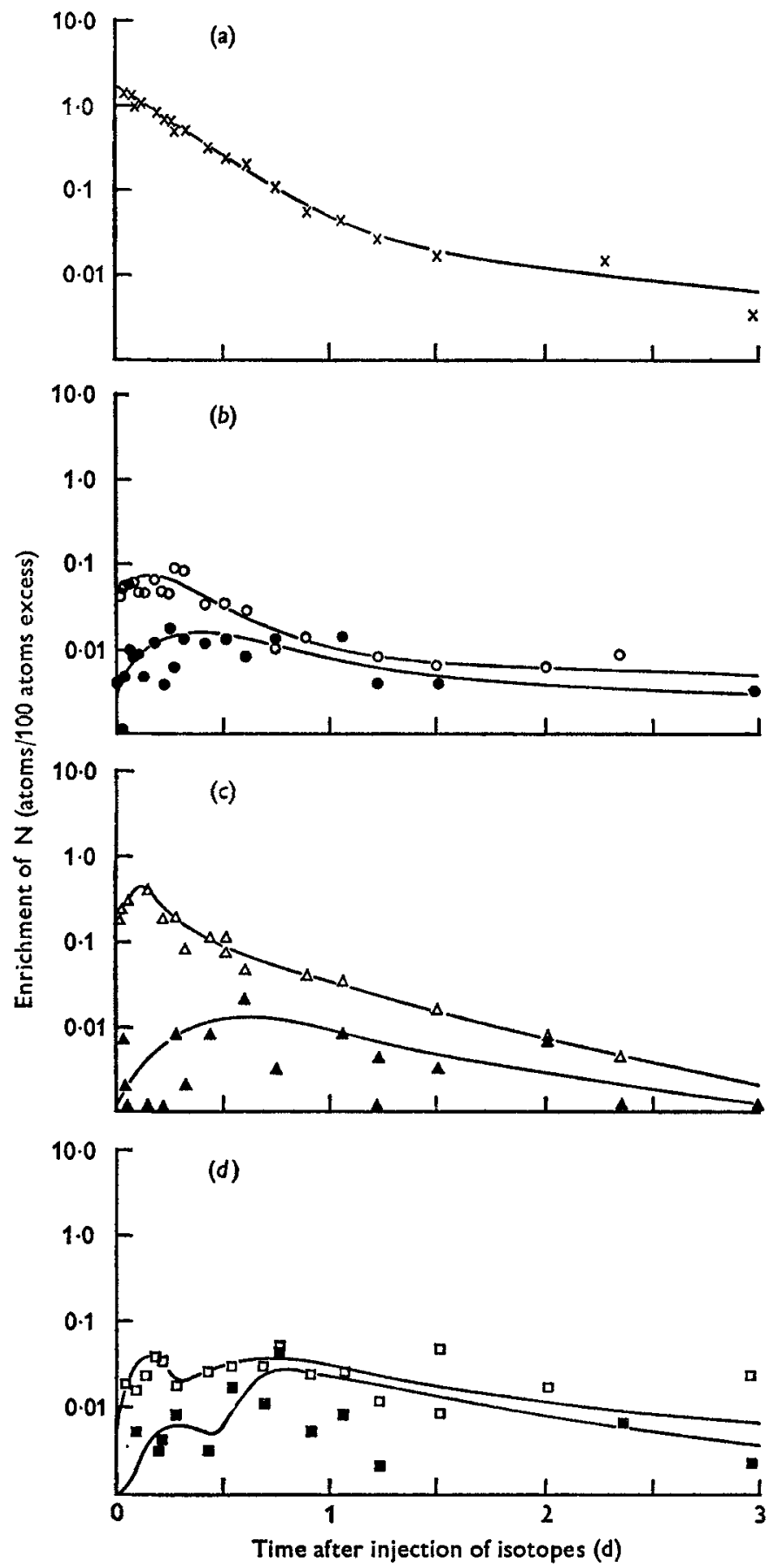

Fig. 2. Expt 2. Single injection of $\left[{ }^{15} \mathrm{~N}\right]$ urea into blood. 'Enrichment-with-time' curves after a single injection of $\left[{ }^{15} \mathrm{~N}\right]$ urea into the blood of sheep $\mathrm{J}$ for $(a)$ urea-N $(X)$ in the plasma; (b) ammonia- $\mathrm{N}(\mathrm{O})$ and bacterial $\mathrm{N}(0)$ in the rumen; (c) $\mathrm{NH}_{3}-\mathrm{N}(\Delta)$ and debris $\mathrm{N}(\Delta)$ in the caecum; (d) $\mathrm{NH}_{3}-\mathrm{N}(\square)$ and bacterial $N(\square)$ in the rectum. For experimental details, see pp. 128-9 and for explanation of 'debris', see p. I29. 
Vol. 35
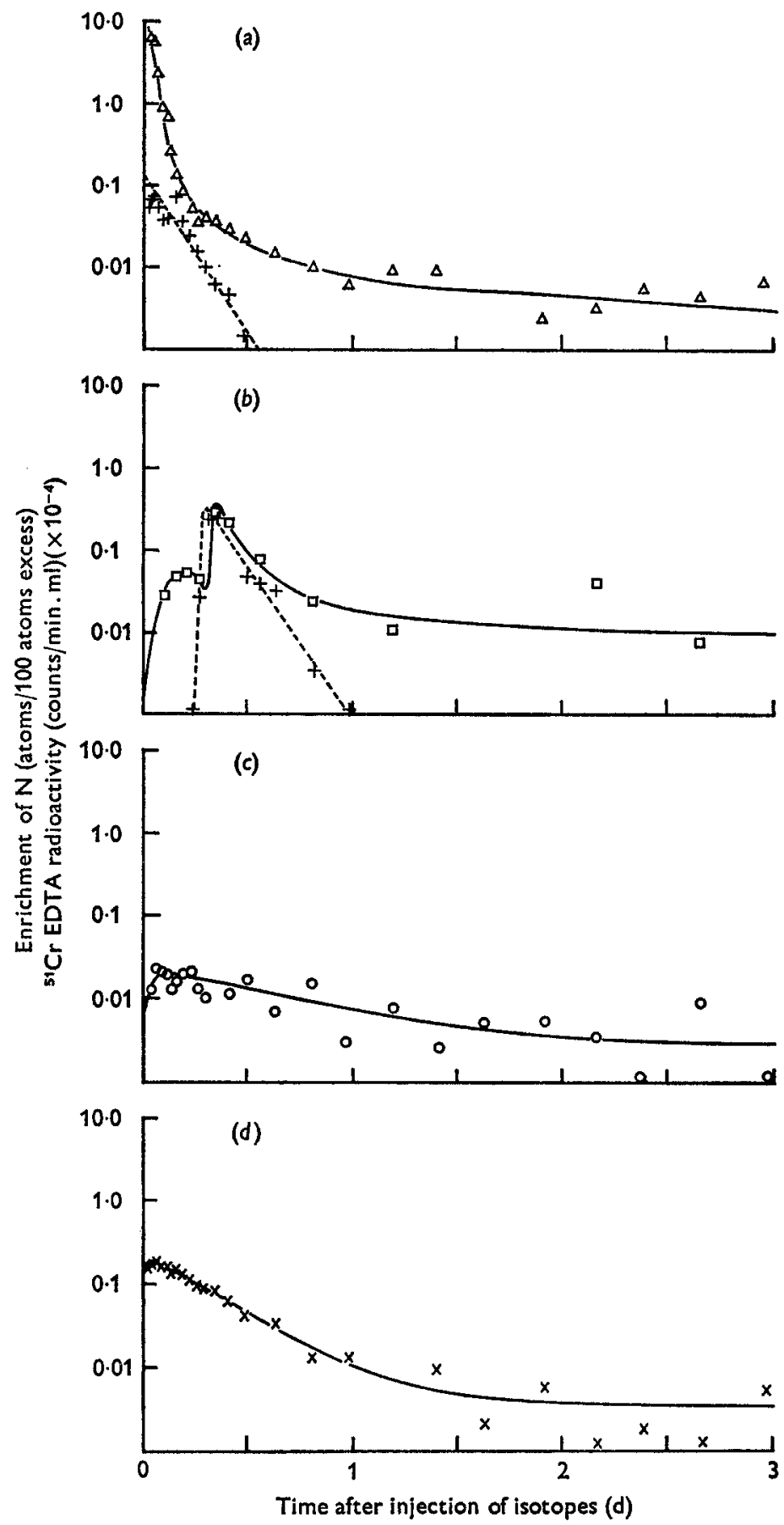

Fig. 3. Expt 3. Injection of $\left({ }^{15} \mathrm{NH}_{4}\right)_{2} \mathrm{SO}_{4}$ and ${ }^{51} \mathrm{Cr} \mathrm{EDTA}$ into the caecum. 'Enrichmentwith-time' curves after a single injection of $\left({ }^{15} \mathrm{NH}_{4}\right)_{2} \mathrm{SO}_{4}$ into the caecum of sheep $\mathrm{S}$ for (a) caecal ammonia- $\mathrm{N}(\triangle)$; (b) faecal $\mathrm{NH}_{3}-\mathrm{N}(\square)$; (c) rumen $\mathrm{NH}_{3}-\mathrm{N}(O)$; (d) plasma urea-N $(x)$. Injection of ${ }^{51} \mathrm{Cr}$ EDTA was made simultaneously and its specific radioactivity with time after injection in the water of the caecum and rectum is also given $(t)$. For experimental details, see pp. 128-9 and for explanation of debris, see p. 129 . 
of the injected solution containing the tracers. The volume of water in the caecum and the rates of flow of water, and $\mathrm{NH}_{3}$, from the caecum were calculated as for the rumen (Table 4, sheep S).

The area under the curve describing appearance of ${ }^{15} \mathrm{~N}$ in rumen fuid $\mathrm{NH}_{3}$ during the period following the ${ }^{15} \mathrm{NH}_{4}{ }^{+}$injection (Fig. $3 c$ ) was used to calculate the proportion of $\mathrm{NH}_{3}-\mathrm{N}$ in rumen fluid derived from caecal fluid $\mathrm{NH}_{3}$ (see Table 5, Expt 3). Similarly, the area describing the appearance of ${ }^{15} \mathrm{~N}$ in plasma urea (Fig. $3 d$ ) was used to calculate the proportion of urea-N derived from caecal fluid $\mathrm{NH}_{3}$ (Table 5, Expt 3).

The appearance of ${ }^{15} \mathrm{~N}$ in faecal fluid $\mathrm{NH}_{3}$ after the intracaecal injection of $\left({ }^{15} \mathrm{NH}_{4}\right)_{2} \mathrm{SO}_{4}$ and ${ }^{51} \mathrm{Cr}$ EDTA was described by a curve that was apparently composed of two processes of build-up and decay. The second process of build-up and decay corresponded closely in time with the curve for first appearance of ${ }^{51} \mathrm{Cr}$ EDTA in faecal water at about $5 \cdot 7 \mathrm{~h}$ (Fig. 3 b), suggesting that it represented that part of the injected ${ }^{15} \mathrm{~N}$ which passed through the large intestine from the caecum to the rectum. The mean transit time for movement of ${ }^{51} \mathrm{Cr}$ EDTA from the caecum to the rectum $(9.3 \mathrm{~h})$ corresponded closely with the estimate obtained from the intraruminal ${ }^{51} \mathrm{Cr}$ EDTA injection experiment $(9 \cdot 7 \mathrm{~h})$.

The rate of synthesis of urea (irreversible loss rate) as estimated from intravenous injection of $\left[{ }^{14} \mathrm{C}\right]$ urea in this experiment was $15 \cdot 7 \mathrm{~g} \mathrm{~N} / \mathrm{d}$.

\section{Quantitative transfers of $\mathrm{N}$ through and between rumen $\mathrm{NH}_{3}$, plasma urea and caecal $\mathrm{NH}_{3}$}

From knowledge of the rates of irreversible loss of $\mathrm{N}$ from each sampled pool (Table 3) and the proportions of those pools derived from the other two pools (Table 5), the fluxes of $\mathrm{N}$ through and transfers of $\mathrm{N}$ between all pools (see Fig. 4) were calculated as described in the Appendix. These values, obtained using results from all three experiments (Fig. 4), vary only slightly from those obtained in individual experiments (e.g. Table 3 ).

\section{DISCUSSION}

\section{Interpretation of isotope kinetics}

A basic assumption necessary for the kinetic analysis of isotope dilution results is that the animal and therefore the system of $\mathrm{N}$ pools and $\mathrm{N}$ transactions in the body was in a steady-state throughout the $3 \mathrm{~d}$ experimental period. Although there were variations between samples in the concentrations of $\mathrm{NH}_{3}$ in rumen, caecal and faecal water (Table 2), the mean pool sizes were constant in the $3 \mathrm{~d}$ experimental period, as indicated by the non-significant regressions of concentrations $v$. time. This indicated that, with the hourly feeding regimen used, these conditions were largely fulfilled.

In the present study, when solutions containing ${ }^{15} \mathrm{NH}_{4}{ }^{+}$were injected into the rumen and caecum, ${ }^{51} \mathrm{Cr}$ EDTA was included in the same solutions in order to obtain independent estimates of the volume of distribution of the injected ${ }^{15} \mathrm{NH}_{4}{ }^{+}$solutions and their rates of distribution through the primary (mixing) pools. The results in 
Figs. $x a$ and $3 a$ indicate that ${ }^{51} \mathrm{Cr}$ EDTA solution mixed rapidly in the water in the rumen and caecum and also that the rates of flow of water were constant throughout the experimental period. Thus, the multi-exponential nature of the 'enrichmentwith-time' curves for $\mathrm{NH}_{3}$ in the rumen and caecal fluids was not an artifact of water kinetics and therefore actually represented the processes of $\mathrm{NH}_{3}-\mathrm{N}$ dilution in these organs. In addition, the pattern of appearance of ${ }^{51} \mathrm{Cr} \mathrm{EDTA}$ in other pools of the digestive tract following injection into the rumen or caecum provided estimates of the times of transit of digesta through the digestive tract between rumen and caecum, and the caecum and rectum (see Figs. I and 3). However, these ${ }^{51} \mathrm{Cr}$ EDTA curves require careful interpretation as digesta do not move at the same rate as ${ }^{51} \mathrm{Cr}$ EDTA which moves with the water component (Ellis \& Huston, 1968). The complex shapes of some 'enrichment-with-time' curves for $\mathrm{N}$ compounds in the body system as seen in Figs. I and 3 are readily explained by the different rates of arrival of ${ }^{15} \mathrm{~N}$ at these organs by way of the blood and the digesta.

The maximum amount of information was obtained from this study by combining the results of the three experiments, assuming that $\mathrm{N}$ transactions in all three animals were similar. It must be stressed that this assumption could be a source of error. An indication of the likely similarity in $\mathrm{N}$ metabolism between the sheep is obtainable from Table 2 which gives comparative values for concentrations of nitrogenous compounds in various body pools. Although small differences between animals existed, it was considered justifiable to combine the three experiments, thus enabling the general, three-pool, open compartment to be solved explicitly (see Appendix). A further justification of this procedure could be drawn from comparison of the rates of urea synthesis, i.e. $15^{\cdot} \pm 0^{\cdot} 6 \mathrm{~g} \mathrm{~N} / \mathrm{d}$, since this major process reflects various facets of over-all $\mathrm{N}$ metabolism. In addition, simplified two-pool, open-compartment models when solved using results from any two experiments (see Appendix) are in good agreement with the single, three-pool model obtained using, simultaneously, results from all three experiments.

\section{$N$ metabolism in the rumen}

The estimates of $\mathrm{N}$ transactions in the rumen were essentially similar to those reported previously (Nolan \& Leng, r 972; Nolan, 1975). Two differences are worthy of mention. There was apparently a more extensive degradation of dietary crude protein, indicating that the extent of degradation may vary between different batches of lucerne chaff, and a more extensive recycling of $\mathrm{N}$ through the rumen $\mathrm{NH}_{3}$ pool indicating that there was extensive lysis and degradation of micro-organisms in situ (see Nolan \& Leng, 1972).

The relatively low proportion of bacterial $\mathrm{N}$ derived from rumen $\mathrm{NH}_{3}$ is noteworthy since it indicates extensive use of non- $\mathrm{NH}_{3}-\mathrm{N}$ sources for microbial growth (see Nolan, 1975). However, the results should be interpreted cautiously as the bacteria isolated may not have been representative of all species of rumen micro-organisms. Protozoa were not isolated, and the cellulolytic micro-organisms (which derive nearly all their $\mathrm{N}$ from $\mathrm{NH}_{3}$ ), and which adhere closely to plant material (Hungate, 1966) would tend to be selectively removed by the differential 


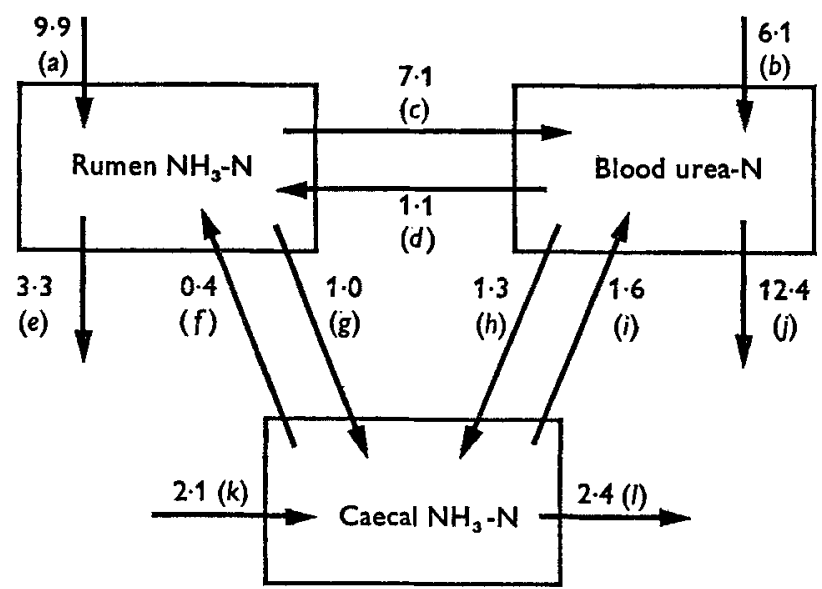

Fig. 4. A general three-pool, open-compartment model for nitrogen transactions associated with rumen fluid ammonia, plasma urea and caecal fluid $\mathrm{NH}_{3}$ for sheep consuming approximately $600 \mathrm{~g}$ chaffed lucerne hay $/ \mathrm{d}$. Rates of flow of $\mathrm{N}(\mathrm{g} / \mathrm{d})$ represented in the model are often a composite of several pathways of transfer. The important components of these multiple pathways are: (a) $\mathrm{NH}_{3}$ derived from dietary and endogenous sources; (b) urea formed from $\mathrm{NH}_{3}$ derived during degradation of amino acids in the body, but excluding urea derived from microbial amino acids which were derived from rumen $\mathrm{NH}_{3} ;(c)$ urea formed from $\mathrm{NH}_{3}(\mathrm{I})$ absorbed from the forestomachs, (2) from digestion and metabolism of rumen microbial amino acids; $(d)$ rumen $\mathrm{NH}_{3}$ derived from blood urea; $(e)$ amino acids of rumen microbes synthesized into body tissues; $(f)$ rumen $\mathrm{NH}_{3}$ derived from caecal $\mathrm{NH}_{3}$ by way of materials other than blood urea; $(g)$ caecal $\mathrm{NH}_{3}$ derived from rumen micro-organisms; $(h)$ caecal $\mathrm{NH}_{3}$ derived from blood urea; (i) plasma urea formed from absorbed caecal $\mathrm{NH}_{3} ;(j)$ excretion of urea in the urine; $(k)$ caecal $\mathrm{NH}_{3}$ from previously undigested endogenous and other miscellaneous $\mathrm{N}$ (dietary $\mathrm{N}$ and part of microbial $\mathrm{N}$ ); $(l)$ caecal $\mathrm{NH}_{3}-\mathrm{N}$ synthesized into body tissues plus a component of faecal $\mathrm{N}$ excretion.

centrifugation techniques used to isolate the rumen bacteria. The techniques for separating the bacteria may have, in addition, caused losses of soluble cell proteins.

\section{$N$ metabolism in the caecum}

The $\mathrm{N}$ for microbial growth in the caecum is derived from undigested food and microbial cells from the rumen, undigested endogenous $\mathrm{N}$, urea- $\mathrm{N}$ from the blood and perhaps, $\mathrm{N}$ from degradation of caecal micro-organisms following lysis.

In the present study, the total rate of flux of $\mathrm{NH}_{3}$ through the caecal $\mathrm{NH}_{3}$ pools was $4.8 \mathrm{~g} \mathrm{~N} / \mathrm{d}$ (Table 3 ) $; 4.2 \mathrm{~g} \mathrm{~N} / \mathrm{d}$ passed through the caecal fluid $\mathrm{NH}_{3}$ pool and was irreversibly lost and $\mathrm{I} \cdot 3 \mathrm{~g} \mathrm{~N} / \mathrm{d}$ was derived directly from blood urea (Fig. 4). A large proportion of the $\mathrm{NH}_{3}$ that entered the caecal fluid $\mathrm{NH}_{3}$ pool $(3 \cdot \mathrm{I} \mathrm{g} \mathrm{N} /$ d, i.e. $2 \cdot \mathrm{I}+\mathrm{I} \cdot 0$; see Fig. 4) was thus not derived directly from blood urea but rather from fermentation of other nitrogenous compounds.

The difference between the total flux rate of $\mathrm{NH}_{3}$ through the caecal fluid pool $\left(4^{\circ} 8 \mathrm{~g} \mathrm{~N} / \mathrm{d}\right)$ and the irreversible loss rate from the pool $(4.2 \mathrm{~g} \mathrm{~N} / \mathrm{d})$ is a measure of the quantity of $\mathrm{NH}_{3}$ recycled to the pool $(0.6 \mathrm{~g} \mathrm{~N} / \mathrm{d})$. It can be calculated from the model (Fig. 4) that very little ${ }^{15} \mathrm{NH}_{3}$ leaves the caecum and returns to the caecal fluid $\mathrm{NH}_{3}$ pool by way of pathways exterior to the caecum. It is therefore likely that most 
of the $\mathrm{N}$ that recycles to the $\mathrm{NH}_{3}$ pool in caecal fluid does so within the caecum itself, perhaps indicating that there is continuous lysis of micro-organisms or breakdown of microbial exudates, or both. It is also probable that turnover of micro-organisms also occurs in the colon and rectum resulting in continuous exchange of $\mathrm{N}$ between $\mathrm{NH}_{3}$ in the gut and urea in the blood.

The quantities of $\mathrm{N}$ that entered the caecal fluid $\mathrm{NH}_{3}$ pool from various sources are summarized in Fig. 4.

\section{$N$ metabolism in the large intestine posterior to the caecum}

Of the blood urea $\mathrm{I} 3 \%$ was derived from caecal fluid $\mathrm{NH}_{3}$ by absorption from the large intestine (Table 5). Thus of the $4.8 \mathrm{~g} \mathrm{NH}_{3}-\mathrm{N} / \mathrm{d}$ that entered the $\mathrm{NH}_{3}$ pool in caecal fluid, $30-40 \%$ was eventually incorporated into urea.

A large proportion (approximately $3.0 \mathrm{~g} / \mathrm{d}$ ) of caecal fluid $\mathrm{NH}_{3}-\mathrm{N}$ was therefore not incorporated into urea in the body nor was it all excreted in faecal $\mathrm{N}$ components (see Nolan \& Leng, 1972), indicating that some apparently absorbed $\mathrm{NH}_{3}$ was used in anabolic processes. This is an important finding in view of the extent to which caecal $\mathrm{NH}_{3}-\mathrm{N}$ was transferred to the rumen $(0.4 \mathrm{~g} \mathrm{~N} / \mathrm{d}$; Fig. 4). This quantity of $\mathrm{N}$ did not move to the rumen as part of that transferred by way of blood urea since this would imply that $39 \%$ of $\mathrm{N}$ incorporated into blood urea was derived from caecal fluid $\mathrm{NH}_{3}$, instead of the measured $13 \%$ (Table 5 ). The actual transfer of this $\mathrm{N}$ to the rumen can be accounted for only by postulating that caecal fluid $\mathrm{NH}_{3}-\mathrm{N}$ is transported to the rumen in nitrogenous compounds other than urea. This could occur, for example, if caecal fluid $\mathrm{NH}_{3}$ is utilized in the liver for synthesis of non-essential amino acids which are subsequently transferred to the rumen; e.g. aspartic acid, glutamic acid (and glutamine) are compounds that could effect this transfer. Studies of incorporation of ${ }^{15} \mathrm{~N}$ into plasma amino acids and its entry into rumen $\mathrm{NH}_{3}$ after injection of ${ }^{15} \mathrm{NH}_{4}{ }^{+}$salts into the caecum or into the portal blood may provide a useful means of testing these suggestions. However, if the findings are substantiated, the appreciable gains of $\mathrm{N}$ between the mouth and duodenum of sheep, found in a number of studies (see, for instance, Hogan, Weston \& Lindsay, I969; Hume, Moir \& Somers, 1970) are more readily explained.

In the present study it was assumed that all urea degradation in the body occurred within the digestive tract since this appears to be the only part of the body where urease occurs. The total quantity of urea degraded, given by the difference between the mean rate of total urea synthesis (estimated using $\left[{ }^{14} \mathrm{C}\right]$ urea), $15^{\cdot} \mathrm{I} \mathrm{N} / \mathrm{d}$, and the mean rate of urea excretion, $9.3 \mathrm{~g} \mathrm{~N} / \mathrm{d}$ (Table I) was $5.8 \mathrm{~g} \mathrm{~N} / \mathrm{d}$. The quantity of blood urea entering the rumen was $\mathrm{I} \cdot \mathrm{r}$ g N/d (see Fig. 4) and thus only $19 \%$ of the urea degraded in the body was accounted for by entry of urea- $\mathrm{N}$ into the rumen fluid $\mathrm{NH}_{3}$ pool. Because this result is so different from previously accepted concepts of urea recycling in ruminants, some discussion of possible sources of errors in the present procedures is warranted. One possible source of error is that urea-N from the blood could be transferred directly to rumen bacteria without first mixing in the $\mathrm{NH}_{3}$ pool in rumen fluid (Cocimano, 1972). This did not occur in the present study as indicated by the similarity of the ratio, area under the curve for the rumen fluid 
$\mathrm{NH}_{3}-\mathrm{N}$ pool: area under the curve for bacterial $\mathrm{N}$ pool, irrespective of whether ${ }^{15} \mathrm{~N}$ was administered by way of the blood urea pool or the rumen $\mathrm{NH}_{3}$ pool (see Table 5 ).

The quantity of urea estimated to be moving into the rumen can be readily accounted for by transfer only in salivary secretions (see Nolan \& Leng, 1973). This concept contradicts the view of Houpt (1970), who suggested that diffusion of urea through the rumen wall is the predominant process for urea movement into the rumen. However, on the basis of arterio-venous differences in blood urea concentration across the rumen of sheep given a diet of lucerne chaff, Hecker \& Nolan (1971) suggested that there was no significant transfer of urea through the rumen wall. It seems likely that urea transfer to the rumen of sheep given a lucerne diet may occur mainly through the saliva and may be quantitatively less important than has often been supposed.

The relatively large proportion of urea that was degraded without apparently entering the rumen in the present study was indirect evidence for the hypothesis that most of the urea degradation in the body occurs in the lower digestive tract. However, there was also direct evidence that urea is transferred from the blood to the caecum (Fig. 2). Following injection of $\left[{ }^{15} \mathrm{~N}\right]$ urea into the blood, enriched $\mathrm{NH}_{3}$ appeared in the caecum almost immediately, indicating that blood urea was either transferred across the caecal wall or entered the small intestine close to the caecum and was quickly transferred to it. In the studies of Clarke, Ellinger \& Phillipson (I966) only small quantities of urea were found in digesta passing from the ileum to the caecum in sheep given a stalky, chopped grass diet but about $2 \mathrm{~g} \mathrm{NH}_{3}-\mathrm{N}$ of unknown origin passed daily from the terminal ileum in sheep given a lucerne diet (Coelho da Silva, Seeley, Thomson, Beever \& Armstrong, 1972). This $\mathrm{NH}_{3}$ may have been derived from hydrolysis of urea that enters the small intestines from the blood, since urease activity is known to occur in the ileum (Sidhu, Jones \& Tillman, 1968; Hecker, 197r).

In the present study there was also evidence for transfer of blood urea across the wall of the lower colon or the rectum, or both. After injection of $\left({ }^{15} \mathrm{NH}_{4}\right)_{2} \mathrm{SO}_{4}$ into the caecum, $\mathrm{NH}_{3}$ in faecal water was immediately labelled. Enrichment values reached an initial maximum at about $5 \mathrm{~h}$ then began to decrease: a secondary increase in $\mathrm{NH}_{3}$ enrichment occurred at $8.5 \mathrm{~h}$ and this almost coincided with the arrival at the rectum of digesta that moved at the same rate as ${ }^{51} \mathrm{Cr}$ EDTA (see Fig. $3 b$ ). It is probable that entry and hydrolysis of urea from the blood and reabsorption of the resulting $\mathrm{NH}_{3}$ occurred along the length of the large intestine as was suggested for sheep (Hecker, I967) and for man (Wolpert, Phillips \& Summerskill, 1971).

Transfer of urea from the blood to the lumen of the intestines occurs in the rabbit (Houpt, 1963 ), dog (Hakim \& Lifson, 1964), rat (Evrard, Hoet, Eyssen, Charlier \& Sacquet, 1964) and man (Walser \& Bodenlos, 1959). However, the mechanism and pathways for transfer of urea are largely unknown. Urea enters the abomasum of sheep in gastric secretions (Harrop \& Phillipson, 1974) and presumably in pancreatic and bile fluids. Furthermore, it seems unlikely that urea, which is present throughout the body water, would be entirely prevented from moving across mucosal membranes during movement of water (Hakim \& Lifson, 1964). Concentrations of urea and $\mathrm{NH}_{3}$ found in contents of the small intestine of sheep and horses (Hecker, 1971) may be 
explained by the hypothesis that urea enters the gut in various secretions, and that concentrations along the small intestine tend to approach those of the blood. Other estimates of the urea content of intestinal digesta that support the hypothesis have been obtained recently in sheep and kangaroos (P. W. Kemp and J. V. Nolan, unpublished results). On reaching areas of high bacterial urease activity in the lower ileum and large intestine, the urea in intestinal fluid would be converted to $\mathrm{NH}_{3}$ which might in turn be utilized by micro-organisms, or absorbed. Absorption of $\mathrm{NH}_{3}$ from the ileum and large intestine is likely to be facilitated by the relatively high $\mathrm{pH}$ of digesta in these organs ( $\mathrm{pH} 7-8)$.

In this study, when the measured inputs of endogenous urea into the rumen and caecum are added together, about half the estimated total urea degradation in the body was accounted for; it appears likely that urea hydrolysis in the abomasum, terminal ileum, and the colon and rectum may have accounted for the remaining amount.

On the basis of the above considerations it seems reasonable to postulate that urea enters the digestive tract at all levels, and that transfer of urea occurs with the water of, for example, saliva, bile, gastric and pancreatic juices, mucus and other intestinal secretions.

The finding that the main entry of blood urea into the digestive tract occurs postruminally in sheep is of particular importance because it invalidates numerous studies in which estimates of transfer of urea to the rumen, and estimates of the nutritional importance of this transfer, have been made on the assumption that $\left[{ }^{14} \mathrm{C}\right]$ urea degradation occurs only in the rumen.

The nutritional significance of urea degradation in the intestines of man was discussed recently by Richards (1972), but its importance in the hind gut of ruminants is not clear. When urea is hydrolysed in the presence of bacterial urease, the $\mathrm{NH}_{3}$ is available for microbial protein synthesis or, upon absorption, for non-essential amino acid synthesis in the liver. These non-essential amino acids may supply tissue requirements if there is surplus supply of essential amino acids (Giordano, 1963; Salter, 1973). The latter are synthesized by micro-organisms in the large intestine but it appears to be generally believed that amino acids are not absorbed in appreciable quantities from this organ. An important consequence of urea degradation in the intestines may be that a source of $\mathrm{N}$ is always available for microbial growth. There are suggestions that, during periods of prolonged undernutrition, there may be an increase in the rates of fermentation in the large intestine relative to the rumen, perhaps because deficiencies of $\mathrm{N}$ or sulphur limit microbial growth in the rumen (Bird, 1972; Murray, 1973). A consequence of urea transfer to the lower digestive tract under these conditions is that $\mathrm{N}$ is unlikely! to limit hind gut fermentation, which maintains a supply of energy substrates (i.e. volatile fatty acids) to the animal.

\section{A model for $N$ metabolism in sheep}

Previously, using available knowledge and isotope experiments, a quantitative model for $\mathrm{N}$ metabolism in sheep was proposed (Nolan \& Leng, 1972). A simplified version of this model comprising the previous results and those presented here and 
taking into account the time delays ('lags') between rumen, small intestinal, caecal and faecal pools has been used in simulation studies on a digital computer. Simulation of the isotope experiments described above has produced responses which satisfactorily reproduce the experimental curves obtained in the present study and also some results of independent experiments (see Mazanov \& Nolan, I976).

The authors are indebted to the Australian Meat Research Committee, the Australian Research Grants Committee and the Australian Wool Research Committee for financial support for this project, and to Dr V.J. Bofinger who helped with the model analyses. The skilled technical assistance of Miss C. Allington and Messrs F. M. Ball and S. Stachiw is also gratefully acknowledged.

\section{APPENDIX}

When tracer dilution experiments are done for a sufficiently long period and numerous pools are sampled, it is possible to analyse the results without the use of multi-exponential curve-fitting procedures. Furthermore, relatively simple, multipool models may be described quantitatively without recourse to solving simultaneous differential equations, by considering only the net tracer movements during an experiment, and thus removing time as a variable (e.g., see Mann \& Gurpide, I966; Depocas \& DeFreitas, I970). Using equations given by Mann \& Gurpide (I966), it is possible to solve any general, open-compartment models with $n$ pools using values obtainable in $n$ different tracer experiments made under, ideally, identical conditions, provided that each pool is the site of administration of tracer while it and all other pools are sampled.

These procedures in slightly modified form have been used in the present study in order to obtain a unique solution to a general three-pool, open-compartment model (i.e. all possible pathways are assumed) in steady-state, where the three pools are rumen $\mathrm{NH}_{3}$ (pool I), plasma urea (pool 2) and caecal $\mathrm{NH}_{3}$ (pool 3). Flow-rates (mass/ unit time) (cf. the more usual rate-constants) are denoted in Fig. 5 by $a, b, c, \ldots, l$.

Information allowing a unique solution to the model is provided by the three experiments reported in this paper. For example, in Expt I, where pool I was the site of injection of tracer, estimates were made of the rate of irreversible loss of $\mathrm{N}$ from that pool $(10.7 \mathrm{~g} \mathrm{~N} / \mathrm{d})$ and of the relative proportions of $\mathrm{N}$ in each of the two other pools derived from pool I (i.e., pool I I*O, pool 20.52 , pool 30.39 ; see Table 5 , p. 134). In the instance of single-injection experiments, the proportion of $\mathrm{N}$ in any one pool derived from another was evaluated from the relative ratios of areas under the 'enrichment-with-time' curves. (These areas can be determined by any suitable numerical procedure (e.g. planimetry, numerical quadrature; see Nolan \& Leng, 1974). In the instance of continuous-infusion experiments, the same values are given by the relative ratios, labelled: unlabelled material at the 'plateau' in each of the pools (see Mann \& Gurpide, 1966)).

Consider Expt $\mathrm{I}$ in which tracer was injected into pool $\mathrm{I}$. The estimated rate of irreversible loss of tracer (unlabelled material) from pool I was 10.7 $\mathrm{g} \mathrm{N} / \mathrm{d}$ and hence 


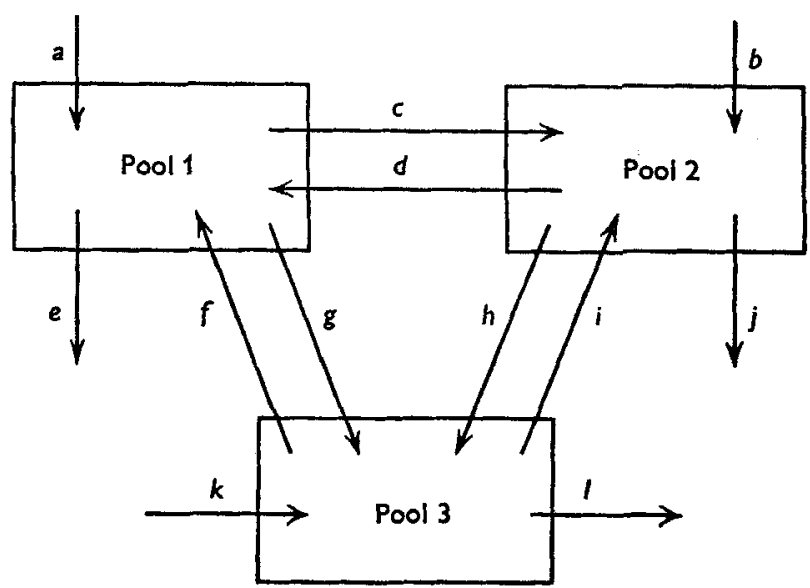

Fig. 5. A general, three-pool, open-compartment model for nitrogen transactions associated withr umen ammonia (pool 1), plasma urea (pool 2) and caecal $\mathrm{NH}_{3}$ (pool 3 ); $a, b, c, \ldots, l$ are the rates of flow of material (mass/unit time).

the rate of irreversible loss of tracer was $(10.7 \times \mathrm{r})$ units/d, since labelling in this pool was given a nominal value of $\mathrm{I}$. If entry into the pool is designated by a positive sign and loss by a negative sign, the irreversible loss of tracer from pool $\mathrm{I}$ is given by:

$$
-c+0.52 d-g+0.39 f-e=-10.7 .
$$

Also, because $e, j$ and $l$ represent the only pathways by which tracer leaving pool I can be irreversibly lost from this system,

$$
-e-0.39 l-0.52 j=-10.7 \text {. }
$$

Furthermore, if tracer steady-state is to exist in pool 3 ,

$$
-0.39 l-0.39 i-0.52 h+g-0.39 f=0 .
$$

(It will be noted that $a=0$ and $k=0$ in the above equations, since no tracer flows by way of these pathways.)

Considering the movement of tracee (unlabelled material) through pool $\mathrm{x}$, in steady-state,

$$
a-c+d-g+f-e=0 .
$$

Similar experimental values are available in Tables 3 and 5 which allow four equations to bé written for pool 2, using results of Expt 2, and four for pool 3, using results of Expt 3, making a total of twelve independent, simultaneous equations with twelve unknown values. These may be solved and the values so obtained are given in Fig. 4 .

The flow-rate value $(0.4 \mathrm{~g} \mathrm{~N} / \mathrm{d})$ associated with flow-rate $d$ (i.e. the movement of caecal $\mathrm{NH}_{3}-\mathrm{N}$ to rumen $\mathrm{NH}_{3}$ by way of non-urea intermediates) was studied further, both because the value obtained was small relative to other values in the model and because it seemed possible that this pathway might have negligible quantitative significance. (However, if this pathway is deleted, the number of equations exceeds 
the number of variables and in this instance, in general, no exact solution exists; the pathway is therefore necessary for model balance.)

Simpler two-pool models were also derived using the same equations and the results of any two experiments while excluding all pathways and labelling information relating to the non-existent third pool.

In previous publications, we have obtained estimates for the rate of irreversible flow $(F)$ of $\mathrm{N}$ from a primary pool $(P)$ to a secondary pool $(S)$ from:

$$
F=(\text { secondary:primary curve area ratio) } \times(\text { irreversible loss from } S)
$$

Whenever there is recycling from $S$ to $P$, the total flow rate exceeds the value of $F$ calculated in this way, although in instances where we have used this formula (e.g. Nolan \& Leng, 1972) the difference is likely to be small. The design of the present experiments, which takes into consideration all three pools, obviates this problem and provides an indication of its likely magnitude.

Two- or three-pool models of a whole-animal system (while giving actual flowrates along pathways described in those models) clearly oversimplify more complex processes and do not partition multiple pathways (e.g. consider route $a$; some rumen $\mathrm{NH}_{3}-\mathrm{N}$ reaches blood urea by direct absorption of $\mathrm{NH}_{3}$ which is converted to urea in the liver, while some follows a second pathway as follows: rumen $\mathrm{NH}_{3} \rightarrow$ microbial protein $\rightarrow$ absorbed amino acids $\rightarrow \mathrm{NH}_{3} \rightarrow$ blood urea, and some also passes through other pathways). Thus other criteria are needed to allow the values to be partitioned and fitted to models of a whole-animal system, and auxiliary information about the nature of the model and some assumptions could be used to partition the values given in Fig. 4. Possible procedures are outlined in detail by Nolan (1975) in an example in which a quantitative sub-model for the rumen is derived. Other values can be obtained by repetitive substitution, checking the resulting models' compatibility with other available information from isotope studies, the literature, and from simulation studies (see Mazanov \& Nolan, 1976).

\section{REFERENCES}

Bird, P. R. (1972). Aust. F. biol. Sci. 25, 1073.

Clare, N. T. \& Stevenson, A. E. (1964). N.Z. $\mathscr{H l}$ agric. Res. 7, 198.

Clarke, E. M. W., Ellinger, G. M. \& Phillipson, A. T. (1966). Proc. R. Soc. B 166, 63.

Cocimano, M. R. (1972). Metabolism of urea in sheep. PhD Thesis, The University of New England, Australia.

Coelho da Silva, J. F., Seeley, R. C., Thomson, D. J., Beever, D. E. \& Armstrong, D. G. (I972). Br. F. Nutr. 28,43 .

Depocas, F. \& DeFreitas, A. S. W. (1970). Can. F. Physiol. Pharmacol. 48, 557.

Downes, A. M. \& McDonald, I. W. (rg64). Br. F. Nutr. 18, I53.

Ellis, W. C. \& Huston, J. E. (I968). F. Nutr. 95, 67.

Evrard, E., Hoet, P. P., Eyssen, H., Charlier, H. \& Sacquet, E. (I964). Br. J. exp. Path. $45,409$.

Giordano, C. (1963). F. Lab. clin. Med. 62, 231.

Hakim, A. A. \& Lifson, N. (1964). Am. Y. Physiol. 206, I3 5.

Harrop, C. J. F. \& Phillipson, A. T. (r974). F. agric. Sci., Camb. 83, 237.

Hecker, J. F. ( 1967$)$. Studies on the metabolism of nitrogenous compounds in the large intestine of herbivores. PhD Thesis, University of Cambridge.

Hecker, J. F. (1971). Br. F. Nutr. 26, 135.

Hecker, J. F. \& Nolan, J. V. (1971). Aust. F. biol. Sci. 24, 403.

Hogan, J. P., Weston, R. H. \& Lindsay, J. R. (1969). Aust.. agric. Res. 20, 925.

Houpt, T. R. (1963). Am. F. Physiol. 205, 1144. 
Houpt, T. R. (1970). In The Physiology of Digestion and Metabolism in the Ruminant, p. Ir9 [A. T. Phillipson, editor]. Newcastle upon Tyne: Oriel Press.

Hume, I. D., Moir, R. J. \& Somers, M. (1970). Aust. F. agric. Res. 2r, 283.

Hungate, R. E. (1 966). The Rumen and its Microbes. New York: Academic Press.

Levenson, S. M., Crowley, L. V., Horowitz, R. E. \& Malm, O. J. (1959). F. biol. Chem. 234, 206r.

Mann, J. \& Gurpide, E. (r966). \%. clin. Endocr, 26, I346.

Marsh, W. H., Fingerhut, B. \& Kirsch, E. (1957). Am. F. clin. Path. 28, 681.

Mazanov, A. \& Nolan, J. V. (1976). Br. F. Nutr. 35, 149.

Murray, R. M. (1973). Nutrition and digestive function of the ruminant. PhD Thesis, The University of New England, Australia.

Nolan, J. V. (1975). In Digestion and Metabolism in the Ruminant [I. W. McDonald and A. C. I. Warner, editors]. Armidale, Australia: University of New England Press.

Nolan, J. V. \& Leng, R. A. (1970). Br. F. Nutr. 24, 905.

Nolan, J. V. \& Leng, R. A. (1972). Br. F. Nutr. 27, 177.

Nolan, J. V. \& Leng, R. A. (1973). Proc. Nutr. Soc. 32, 93.

Nolan, J. V. \& Leng, R. A. (r974). Proc. Nutr. Soc. 33, 1.

Raabe, R. R. (1968). Lab. Pract. 17, 217.

Richards, P. (1972). Am. Y. clin. Nutr. 25, 615.

Salter, D. N. (1973). Proc. Nutr. Soc. 32, 65.

Sidhu, K. S., Jones, E. E. \& Tillman, A. D. (1968). F. Anim. Sci. 27, 1703.

Walser, M. \& Bodenlos, L. J. (1959). F. clin. Invest. 38, 1617.

White, R. G., Steel, J. W., Leng, R. A. \& Luick, J. R. (I969). Biochem. F. II4, 203.

Wolpert, E., Phillips, S. F. \& Summerskill, W. H. J. (1971). Lancet ii, 1387. 